\title{
Common vampire bat attacks on humans in a village of the Amazon region of Brazil
}

\section{Agressões de morcegos hematófagos a pessoas em um povoado da região amazônica do Brasil}

\author{
Maria Cristina Schnei der 1 \\ Joan Aron 2 \\ Carlos Santos-Burgoa 3 \\ Wilson Uieda 4 \\ Sílvia Ruiz-Velazco 5
}

\footnotetext{
1 Pan American Health Organization. 52523 rd Street NW, Washington, DC 20037-2895, U.S.A. 2 Science Communication Studies. 5457 Marsh Hawk Way, Columbia, MD 21045, U.S.A.

3 Instituto de Salud Ambiente y Trabajo. Cerrada del Convento 48-A, Tlalpan, DF 14420, México.

4 Departamento de Zoologia, Instituto de Biociências, Universidade Estadual Paulista. Botucatu, SP 18618-000, Brasil.

5 Universidad Nacional Autonóma de México. Edificio del IIMAS, Ciudad Universitaria, México, DF 045190, México.
}

\begin{abstract}
Many people in Amazonian communities have reported bat bites in the last decade. Bites by vampire bats can potentially transmit rabies to humans. The objective of this study was to analyze factors associated with bat biting in one of these communities. A cross-sectional survey was conducted in a village of gold miners in the Amazonian region of Brazil (160 inhabitants). Bats were captured near people's houses and sent to a lab. Of 129 people interviewed, $41 \%$ had been attacked by a bat at least once, with $92 \%$ of the bites located on the lower limbs. A logistic regression found that adults were bitten around four times more often than children (OR $=$ 3.75, Cl 95\%: 1.46-9.62, $\mathrm{p}=0.036)$. Males were bitten morefrequently than females $(\mathrm{OR}=2.08, \mathrm{Cl}$ 95\%: 0.90-4.76, $p=0.067$ ). Nine Desmodus rotundus and three frugivorous bats were captured and tested negative for rabies. The study suggests that, in an area of gold miners, common vampi re bats are more likely to attack adults and males. The control strategy for human rabies developed in this region should therefore place special emphasis on adult males. There should also be more research on how the search for gold in the Amazonian region places people and the environment at risk.
\end{abstract}

Key words Agression; Chiroptera; Desmodus rotundus

Resumo Agressões de morcegos a pessoas vêm sendo notificadas em várias comuni dades amazôni cas nesta última década. Isto constitui um risco potencial para a raiva humana transmitida por morcegos. O objetivo deste estudo foi de analisar fatores associados a estas agressões em uma destas comunidades. Foi realizado um estudo transversal em um povoado de garimpeiros na Região Amazônica brasileira (160 habitantes). Foi realizada a captura de morcegos junto às casas e foram enviadas amostras para o laboratório. Das 129 pessoas entrevistas, 41\% foram agredi das por morcegos pelo menos uma vez, com 92\% das mordidas localizadas nos dedos dos pés. Por meio de regressão logística, encontrou-se que adultos eram agredidos ao redor de quatro vezes mais do que crianças ( $O R=3,75, I C: 1,46-9,62, p=0,036)$. Homens foram agredidos com maior freqüência do que mulheres ( $O R=2,08$, IC: $0,90-4,76, p=0,067)$. Nove Desmodus rotundus e três morcegos frugí voros foram capturados e resultaram negativos para a rai va. O estudo sugere que, em áreas de garimpo, adultos do sexo masculino têm mai or probabilidade de serem agredi dos por morcegos. As ações de controle para a raiva humana a serem desenvolvi das nestes lugares devem dar ênfase especial a adultos homens. Recomendam-se mais investi gações sobre o modo como o garimpo na Região Amazôni ca está colocando em risco as pessoas e o ambiente. Palavras-chave Agressão; Quirópteros; Desmodus rotundus 


\section{Introduction}

The very first settlers of the Americas reported incidents of bats attacking people and cases of human rabies transmitted by these animals in the early 16th century (Baer, 1982). Hematophagous bats inhabit a territory ranging from the North of Mexico to the North of Argentina (Lord et al., 1975). There are three species of bats that feed on blood: Diphylla ecaudata, Diaemus youngi, and Desmodus rotundus (Uieda, 1989). The latter species, also known as the common vampire, specializes in bleeding mammals and is probably responsible for attacks on people (Greenhall, 1988).

Bats can transmit various diseases to humans, such as arbovirus diseases (Tamsitt \& Valdivieso, 1970), histoplasmosis and trypanosomiasis (Constantine, 1988), leptospirosis, rickettsiosis, and cryptococcosis (Tamsitt \& Valdivieso, 1970), and brucellosis, salmonellosis, and candidiasis (Constantine, 1988). However, the most serious disease that can be transmitted by bats is rabies. This disease has caused numerous deaths in Latin America over the last several decades, where the bat has been identified as the second most important animal species in the transmission of rabies to humans (INPPAZ, 1997).

The first outbreak of human rabies transmitted by hematophagous bats reported in the scientific literature took place in Trinidad in the 1930s, when 55 people died (Verteuil \& Urich, 1935). From the 1930s until the present approximately one thousand deaths attributed to vampire-transmitted rabies have been reported, and this number is probably an underestimate (Alvarez, 1997). The countries that reported the most cases between 1990 and 1995 were Peru (78) and Brazil (43) (Alvarez, 1997). Cases of rabies transmitted by vampire bats occurred mostly in areas with difficult access in the Amazon region of these countries (Schneider \& Santos-Burgoa, 1995).

There are various reports of vampire bats attacking humans without the attack being followed by rabies. This obviously depends on how widespread the virus is in the area. Some of these attacks have taken place among indigenous populations, such as the Yanomami in Venezuela in 1979 (Almansa \& Garcia, 1980). Note that in the latter case deforestation had taken place in the area as a result of lumbering and gold prospecting; it was also reported that the poultry being raised in those communities had been rapidly exterminated before the attacks started. In 1975, a series of attacks on people was reported in Belize after the swine in the area had been slaughtered (MacCarthy, 1989). Gold prospectors in Roraima, Brazil, are frequently attacked by bats (Uieda et al., 1996). A series of attacks in a village in a rural area of Brazil was ascribed to both local environmental changes and a topical pesticide applied to cattle (Costa et al., 1993). Although there are reports of bats attacking people in various countries, the extent of the problem and its associated risk factors are not known.

This paper examines factors associated with high incidence of vampire bat attacks on humans, identifying a potentially high risk for human rabies.

\section{Methods and materials}

A cross-sectional study was conducted in the village of Mina Nova on the island of Aurizona, in the county of Godofredo Viana, located in the extreme northern region of Maranhão State, part of the Amazon region of Brazil (01016' 18" $\mathrm{S}$ and $45 \circ 46^{\prime} 0^{\prime \prime} \mathrm{W}$ ). On this $225 \mathrm{~km}^{2}$ island there are some 20 garimpos debarranco (extensive areas with labor-intensive surface mining of gold) as well as hundreds of individual gold prospectors. Aurizona has extensive gold deposits that have been exploited for several decades. The vegetation consists of mangrove thickets interrupted by extended barren areas where the vegetation has been destroyed by the search for gold. Most inhabitants of Mina Nova were gold prospectors and their wives and children. In the period leading up to the study, the village had experienced attacks by vampire bats but no case of human rabies had been reported. Visits were conducted to all houses occupied by people at the time of the interviews ( $87.5 \%$ of the total). One hundred twenty-nine people (total population $=160$ ) were interviewed, either directly or by proxy in the case of children or absent family members (35\%). The survey requested information about the dwelling and the individuals in the household. Data included type of construction, number of individuals per house, presence of domestic animals, and whether these animals had been bitten by bats (as reported by the respondent). Individual data included gender, age, profession, time of residence in the village, sleeping quarters, time and frequency of bat attacks, location of the last bite, type of protection used, immunization status, treatment preference, and knowledge concerning rabies. Bats were also captured at night to determine whether the rabies virus was circulating in the area (Schneider et al., 1996). 
For the bivariate analysis, the fact of ever having been attacked by bats in Mina Nova was considered a yes/no factor, where "yes" and "no" are analogous to cases and controls in a case-control study. This variable was cross-tabulated one by one with possible explanatory (or "exposure") variables in order to estimate an odds ratio (OR) (ratio of exposure odds among cases to exposure odds among controls) and to apply Fisher's one-tailed exact test. For each possible explanatory variable, these two procedures analyze the proportion of people bitten in relation to the value of that variable (e.g., proportion of males bitten versus proportion of females bitten).

For the multivariate analysis, a logistic regression model was developed, using history of bat attack as the dependent variable and the significant values from the bivariate analysis as the independent variables. STATA version 5 software (STATA Corporation, 1997) was used for all statistical analyses. The final multivariate analysis model was selected by comparing the likelihood of the reduced model with that of the complete model, using the equation $\mathrm{G}=$ -2 In (likelihood of the reduced model/likelihood of the complete model). Variables were retained in the final model if the model's fit using them was significantly improved as shown by the $\mathrm{G}$ statistic.

In addition to individual interviews with residents, bats were captured at night to determine whether the rabies virus was circulating in the area. The researchers selected houses with a high probability of being targets for common vampires, such as those with domestic animals or with people who had been attacked recently. Nets for capturing bats were placed once in each house for a period of 5 hours in the early evening. In 5 houses in Mina Nova, 10 nets measuring about 6 meters each were set up to trap bats. Captured bats were sent to a reference laboratory (Centro de Zoonoses de São Paulo) to be diagnosed for rabies infection (immunofluorescence and biological tests) (Schneider et al., 1996).

\section{Results}

All of the dwellings were built of non-permanent materials, mostly mud and wattle (82\%) with various openings through which bats could easily enter. The homes lacked running water and sewage disposal. None of the houses were connected to the electric utility system, but a few had their own electric power supply. The average household size was 4.26 persons and the average residence time in Mina Nova was 2.7 years. Forty percent of the households raised pigs and several of them also raised other animals such as poultry and goats. These animals are a common feeding source for D. rotundus (Greenhall, 1988). It was reported that $66.7 \%$ of these animals had been attacked by bats. Seventy-one percent of the questionnaires obtained were from adults (over 14 years of age) and $65.9 \%$ were men, most of whom were gold prospectors (98\%). Half of the population older than 7 years of age was literate. Most of the population (86.8\%) slept in hammocks and few (25.8\%) used mosquito nets. Most (83.3\%) of the population did not know which diseases could be transmitted by bats.

Nearly half (41.1\%) of the population had been bitten by bats in Mina Nova, and $23.3 \%$ of the attacks had occurred in the previous 12 months (7.8\% in the previous month). An average of 2.8 attacks (ranging from one attack to 12) was found per person attacked in the previous 12 months. The vast majority of bites were located on the lower limbs (92.45\%). About a third (34.1\%) of the individuals who had been bitten had received some form of preventative treatment for rabies, and $75.9 \%$ of interviewed adults stated that they would prefer pre-exposure rather than post-exposure treatment.

In a bivariate analysis considering history of bat bite as a yes/ no factor, significant variables included: gender, with the risk being greater for males (OR $=2.48, \mathrm{Cl}$ : 1.14-5.41; $\mathrm{p}=$ $0.017) ;$ age, with the risk being greater for adults ( $\mathrm{OR}=4.14 ; \mathrm{Cl}$ : $1.68-10.18 ; \mathrm{p}=0.02)$, and not using a mosquito net $(\mathrm{OR}=2.81 ; \mathrm{Cl}: 1.17$ 6.73; $p=0.016$ ) (Table 1).

In the final multivariate analysis model, use of individual protection was not significant, although use of mosquito nets appeared to be a protective factor against bites $(\mathrm{OR}=0.54 ; \mathrm{Cl}$ : $0.20-1.47 ; p=0.427$ ). However, the study was not powerful enough to detect a risk factor with an OR lower than three for this variable and did not allow for conclusions concerning the use of individual protection against bites. Including the use of individual protection did not significantly increase the model's fit ( $G=2.98, p=$ 5.99, $\mathrm{a}=0.05, \mathrm{gl}=2$ ), and this factor was thus removed from the model. Age as a dichotomous variable was the only variable that showed any association with bites by the common vampire bat $(\mathrm{OR}=3.75, \mathrm{Cl}: 1.46-9.62 ; \mathrm{p}=$ $0.036)$. The odds ratio showing a greater risk for males was decreased slightly when age was controlled $(\mathrm{OR}=2.08, \mathrm{Cl}$ : 0.90-4.76; $\mathrm{p}=0.067)$. For the gender variable, the multivariate analysis was not powerful enough to detect a signifi- 
Table 1

Number of people surveyed, number of people bitten, odds ratio, and confidence interval. Mina Nova, Maranhão State, Brazil.

\begin{tabular}{|c|c|c|c|c|}
\hline Variable & Surveyed & Bitten & OR & $\mathrm{Cl}$ \\
\hline \multicolumn{5}{|l|}{ Gender } \\
\hline Female & 44 & $12(27 \%)$ & & \\
\hline Male & 85 & $41(48 \%)$ & 2.48 & $1.14-5.41$ \\
\hline \multicolumn{5}{|l|}{ Age } \\
\hline Children & 36 & $7(19 \%)$ & & \\
\hline Adults & 92 & $46(50 \%)$ & 4.14 & $1.68-10.18$ \\
\hline \multicolumn{5}{|c|}{ Use mosquito nets } \\
\hline Yes & 33 & $8(24 \%)$ & & \\
\hline No & 95 & $45(47 \%)$ & 2.81 & $1.17-6.73$ \\
\hline \multicolumn{5}{|l|}{ Literate } \\
\hline Yes & 53 & $23(43 \%)$ & & \\
\hline No & 49 & $27(55 \%)$ & 1.60 & $0.74-3.48$ \\
\hline \multicolumn{5}{|c|}{ Knowledge of rabies } \\
\hline Yes & 13 & $7(54 \%)$ & & \\
\hline No & 65 & $34(52 \%)$ & 0.94 & $0.30-2.98$ \\
\hline
\end{tabular}

cant association for an OR below 2.5, but the analysis suggested a tendency for males to be at greater risk of bat bites.

According to the cluster analysis by household, $74.29 \%$ had one or more member that had been attacked by bats in Mina Nova. In all households in Mina Nova that reported animals having been attacked by bats, more than $50 \%$ of the people had been bitten by bats. Including the information on those households with an attacked animal (yes or no), an OR of 15 was found, but the small number of households resulted in a very wide confidence interval ( $\mathrm{Cl}$ : 0.70-709.89, $\mathrm{p}=0.1026$, Fisher's exact test). Therefore, a history of bitten domestic animals in the household tended to be a risk factor for bat bites in human, but the results were not statistically significant.

Nocturnal capture of bats yielded nine D. rotundus (E. Geoffroy, 1810) and three frugivorous bats - 2 Carollia perspicillata (Linnaeus, 1758) and 1 Dermanura cinerea (Gervais, 1856) - which all tested negative for rabies as expected, since there was no epidemiological evidence of the virus circulating in the area at the time of the study (Schneider et al., 1996).

\section{Discussion}

Mina Nova showed a high rate $(41.1 \%)$ of attacks on people by common vampire bats, constituting one among many health hazards for the village. The percentage of people bitten over the twelve months prior to the study (23.3\%) in Mina Nova was comparable to the $22 \%$ and $27 \%$ of people bitten by bats during rabies outbreaks reported in the literature for Belize (MacCarthy, 1989) and Peru (López et al., 1992), respectively.

The houses surveyed in Mina Nova are quite vulnerable to entrance of bats, since they are built in simplefashion with local materials, i.e., mud and wattle walls and thatched roofs, with many openings, both to keep the cost down and to make them cooler in the hot climate. Most people sleep in hammocks without mosquito nets. The men are generally exhausted from the hard physical labor of mining, and alcohol consumption tends to be heavy, thus making them easy prey for bats.

According to the multivariate analysis, adults are more likely to be attacked. Males may also be at greater risk than females, although in the multivariate analysis the effect was not statistically significant. By contrast, in farming areas of Brazil, bat-transmitted rabies is more common in children than adults (Schneider, 1991). It has been suggested that since there are fewer children in gold-mining areas, they are probably less affected (Schneider et al., 1996).

In Mina Nova, the most recent bites were mostly on the lower limbs (92\%), mainly on the feet. In another outbreak of bat bites in Brazil (Costa et al., 1993), most (83\%) of the attacks were also limited to the lower limbs, but the sleeping habits of the victims were not reported. However, among bat-transmitted rabies cases reported in the past decade in Brazil (Schneider, 1991), only 35\% of bites were located on the lower limbs. Half of these cases involved children and took place in rural areas. In the report on the outbreak in Madre de Dios, Peru (López, 1991), the percentage of bites on the lower limbs was slightly lower (67\%) than in Mina Nova, but the author also mentions that nights are cold in Peru, which could require people to cover up more carefully during sleep. In the outbreak that occurred in the Amazon region of Peru (López et al., 1992), 73\% of the attacks was on the head, while feet were bitten only $14 \%$ of the time; however, the report offers no climatic information on the region. It is likely, in fact, that the position of the bite may be associated with climate, sleeping habits, and victim's age. 
Research is also needed to evaluate the risk factor of living in a household whose domestic animals are being attacked by bats. These findings have a plausible biological basis, since it is known that vampire bats return to feed on the same victim more than once. If the usual victim is not readily available, the bats may turn to other prey, possibly humans.

The Brazilian Ministry of Health recommends post-exposure treatment for all individuals attacked by bats (FNS, 1994). However, it is important to consider access to the vaccine in remote areas, far from public health services. In this study, only $34.1 \%$ of the people who had been attacked had received post-exposure treatment. This percentage is quite low, suggesting a serious risk of a human rabies outbreak if the virus were circulating in the region. The study suggests that gold prospectors are at a higher risk than their families, since they work all day in the garimpos, and it would be difficult for them to travel to another town to get anti-rabies treatment. It would thus be relevant to consider pre-exposure rabies prevention in areas with frequent bat attacks, circulating rabies virus, and no local health services. Such a proposal was well received by the people interviewed. Since rabies has a nearly $100 \%$ mortality rate, it would be useful to build a mathematical model to evaluate all possible control actions for human rabies transmitted by vampire bats.

Another potential measure would be to control the vampire bat population. This would have to be carried out by specialists, so as not to endanger the other species of bats in the region. Other actions should aim at preventing attacks, such as educational work encouraging the use of protective devices. Since few people used mosquito nets, their importance as a protective factor in the multivariate analysis could not be ascertained. Another study with a larger sample should thus be performed.
Apart from bat attacks, there are various other health problems in the study area, such as exposure to mercury used to extract gold, Plasmodium falciparum malaria, sexually transmitted diseases, cutaneous leishmaniasis, and widespread acts of violence. Normally there is just one general practitioner located in the county, but at the time of this study there was no physician at all. Gold prospectors work on average 10 hours a day and as much as 24 hours a day in some garimpos. Workers are paid according to the amount of gold they find, and during the three-month rainy season they are out of work, so there is a seasonal exodus of some $35 \%$ of the Mina Nova populace. Any decisions about rabies control must consider a broader context of health and occupational conditions.

Attacks by hematophagous bats on people with the risk of rabies transmission have been a problem in Latin America for centuries. In recent decades reports of bat attacks on people and cases of human rabies transmitted by the common vampire bat have increased, especially in the Amazon region of Peru and Brazil. Several of these outbreaks have been preceded by some change in the local production process, such as the sudden removal of domestic animals as a food source, gold prospecting, or deforestation, processes that would have altered the ecosystem in which the D. rotundus formerly lived. Environmental changes in these areas probably result in more vampire bat attacks on humans.

Therefore, there should also be more research on how gold mining in the Amazon region places people and the environment at risk. Human invasion of preserved areas for gold mining with resulting landslides, use of noisy machinery, hunting of wild game for food, and other forms of aggression against nature probably cause an imbalance in the natural ecosystem. Such exploitation of nature appears to place both current inhabitants and future generations at risk.

\section{Acknowledgments}

This study was supported by funds from the Brazilian National Scientific Development and Research Council and the Brazilian National Health Foundation (FUNASA)/ M inistry of Health. We also wish to thank the field team for their invaluable help: Marisa Cardoso, Benedito Mendonça, José Carlos Silva, Antônio Alves Sobrinho, and other FUNASA staff members in the State of Maranhão. 


\section{References}

ALMANSA, J. C. \& GARCIA, R. C., 1980. Incidencia del murciélago hematófago Desmodus rotundus sobre los indígenas Yanomami de Venezuela. Donana Acta Vertebrata, 7:113-117.

ALVAREZ, E., 1997. Rabia transmitida por vampiros: Distribución, frecuencia e importancia. Técnica Pecuaria en México, 35:93-104.

BAER, G. M., 1982. Rabia bovina paralítica y rabia en el murciélago vampiro. In: Historia Natural dela Rabia (G. M. Baer, org.), pp. 63-83, México, DF: La Prensa Médica Mexicana.

COSTA, M. B.; BONITO, R. F. \& NISHIOKA, S. A., 1993. An outbreak of vampire bat bites in a Brazilian village. Tropical Medicine and Parasitology, 44: 219-220.

CONSTANTINE, D. G., 1988. Transmission of pathogenic microorganisms by vampire bats. In: Natural History of Vampire Bats (A. M. Greenhall \& U. Schmidt, ed.), pp. 167-189, Boca Raton: CRC Press.

FNS (Fundação Nacional de Saúde), 1994. Normas Técnicas de Tratamento Preventivo Contra a Raiva Humana. Brasília: Ministério da Saúde.

GREENHALL, A. M., 1988. Feeding behavior. In: Natural History of Vampire Bats (A. M. Greehall \& U. Schmidt, ed.), pp. 111-131, Boca Raton: CRC Press.

INPPAZ (Pan-American Institute for Food Protection and Zoonoses), 1997. Regional Information on Rabies in the Americas. INPPAZ in the Americas, 5. Buenos Aires: Pan-American Health Organization.

LOPEZ, A., 1991. Presentación del Brote Epidémico de Choque, Madre de Dios (Perú). Reunión de consulta sobre la atención a personas expuestas a la rabia transmitida por vampiros. Washington, DC: Organización Panamericana de Salud.

LOPEZ, A.; MIRANDA, P.; TEJADA, E. \& FISHBEIN, D., 1992. Outbreak of human rabies in the Peruvian jungle. Lancet, 339:408-412.

LORD, R. D.; FUENZALIDA, E.; DELPIETRO, H.; LARGHI, O. P.; DIAZ, A. M. \& LAZARO, L., 1975. Observations on the epizootiology of vampire bat rabies. Bulletin of the Pan American Health Organization, 9:189-195.
MacCARTHY, T., 1989. Human depredation by vampire bats (Desmodus rotundus) following a hog cholera campaign. American Journal of Tropical Medicineand Hygiene, 40:320-322.

SCHNEIDER, M. C., 1991. Presentación del BroteEpidémico de Apiacas, Mato Grosso (Brasil). Reunión de consulta sobre la atención a personas expuestas a la rabia transmitida por vampiros. Washington, DC: Organización Panamericana de Salud.

SCHNEIDER, M. C. \& SANTOS-BURGOA, C. S., 1995. Algunas consideraciones sobre la rabia humana transmitida por murciélago. Salud Pública de Mé xico, 37:354-362.

SCHNEIDER, M. C.; SANTOS-BURGOA, C.; ARON, J.; MUNOZ, B.; RUIZ-VELAZCO, S. \& UIEDA, W., 1996. Potential force of infection of human rabies transmitted by vampire bats in the Amazonian region of Brazil. American Journal of Tropical Medicineand Hygiene, 55:680-684.

STATA CORPORATION, 1997. Stata Statistical Software. Release 5.0. College Station: Stata Corporation.

TAMSITT, J. R. \&VALDIVIESO, D., 1970. Los murciélagos y la salud pública: Estudio con especial referencia a Puerto Rico. Boletín de la Oficina Sanitaria Panamericana, 69:122-140.

UIEDA, W., 1989. Sanguivoria em morcegos. In: VII Encontro Anual de Etologia, Anais, pp. 150-161. Botucatu: Universidade Estadual Paulista.

UIEDA, W.; HAYASHI, M. M.; GOMES, L. H. \& SILVA, M. M. S., 1996. Espécies de quirópteros diagnosticadas com raiva no Brasil. Boletim do Instituto Pasteur, 1:17-36.

VERTEUIL, E. \& URICH, F. W., 1935. The study and control of paralytic rabies transmitted by bats in Trinidad, British West Indies. Royal Society of Tropical Medicineand Hygiene, 4:317-354. 